This is an open access article under the CC BY-NC-ND license (https://creativecommons.org/licenses/by-nc-nd/3.0/) Issue III, November 2020

ISSN 2707-9481

ISBN 978-601-323-207-2

https://doi.org/10.31643/2020.021

\section{Ch. Kalybekova}

Candidate in historical science, Head of the Department of external relations, information and scientific cluster of Ch.Valikhanov Institute of history and ethnology SC MES RK, Kazakhstan Email: K.manara@mail.ru;

ORCID ID: https://orcid.org/0000-0001-5194-6136
T. A. Apendiyev

$\mathrm{PhD}$, Head of the Department of Historical Demography and the Assembly of People of Kazakhstan, Ch. Valikhanov Institute of History and Ethnology, leading researcher, Kazakhstan Email: timur.apendiev@mail.ru; ORCID ID: https://orcid.org/0000-0002-4279-3921

\title{
Archives say: Rehabilitation and Memory
}

\begin{abstract}
Now, the peoples of Kazakhstan, like the entire post-Soviet space, are experiencing a spiritual awakening and a return to traditional origins. It is important that the processes of searching for national identity are the world's historical and socio-cultural tendencies of the modern world. Also, Kazakhstan cannot be called a legal state and take a leading role in the world community without immortalizing the memory of many millions of its citizens who have become victims of political repression. In this regard, it is especially important to understand the tragedies of the 30-50s of the last century, which is characterized by a rupture of traditions, loss of continuity of cultural experience. The problems under consideration have gone through a complex and contradictory path of formation and development, have experienced a long-term negative impact of political and ideological conditions. Therefore, much of what was done earlier requires a serious rethinking, a number of assessments of past events need to be revised on the basis of new archival materials and documents.
\end{abstract}

Keywords: political repression, memory, rehabilitation, labor mobilized, mass persecution.

Cite this article as: Kalybekova M. Ch., Apendiyev T. A. (2020). Arkhivy govoryat: Reabilitatsiya i pamyat' [Archives say: Rehabilitation and Memory]. Challenges of Science. Issue III, p.: 150-153.

https://doi.org/10.31643/2020.021

\section{М. Ч. Калыбекова}

к.и.н., заведующий отделом внешней связи, информационного и научного кластера института истории и этнологии им. Ч.Ч.Валиханова КН

MOH РК, г. Алматы, Казахстан.

Email: K.manara@mail.ru; ORCID ID:

https://orcid.org/0000-0001-5194-6136

\section{Т. А. Апендиев}

$\mathrm{PhD}$, заведующий отделом «Исторической демографии и Ассамблеи народа Казахстана»

Института истории и этнологии им. Ч.Ч.

Валиханова, ВНС, г. Алматы, Казахстан

Email: timur.apendiev@mail.ru; ORCID ID: https://orcid.org/0000-0002-4279-3921

\section{Архивы говорят: Реабилитация и память}

\begin{abstract}
Абстракт. В настоящее время народы Казахстана, как и всего постсоветского пространства, переживают духовное пробуждение и возврат к традиционным истокам. Важно, что процессы поиска национальной идентичности являются всеобщей исторической и социокультурной тенденцией современного мира. Также Казахстан не может называться правовым государством и занять одну из ведущих ролей в мировом сообществе, не увековечив память многих миллионов своих граждан, ставших жертвами политических репрессий. Особенно важным в этой связи является осознание трагедии 30-50-х прошлого столетия, который характеризуется разрывом традиций, утратой преемственности культурного опыта. Рассматриваемая проблематика прошла сложный и противоречивый путь становления и развития, испытала многолетнее негативное воздействие политической и идеологической условии. Таким образом, многое из сделанного ранее требует серьезного
\end{abstract}


переосмысления, ряд оценок событий прошлого нуждается в пересмотре на основании новых архивных материалов и документов.

Ключевые слова: политическая репрессия, память, реабилитация, трудмобилизованные, массовые гонения.

В современных условиях проблема сохранения национальной идентичности, на фоне политической и экономической глобализации, создания новых транснациональных образований как внутри, так и между государствами, возрастания массовых миграции по всему миру, приобретает особую актуальность. В частности, это касается всех современных многонациональных государств, в том числе и Казахстан [1, с.331; 7].

Накануне Дня памяти жертв политических репрессий в своем обращении к казахстанцам Президент РК Токаев К.К. сообщил о создании Государственной комиссии по реабилитации жертв политических репрессий для завершения работы по восстановлению исторической справедливости [2]. Действительно политические репрессии - это живая история жизни нашего народа, связанная со многими нитями сегодняшнего дня. Особенно важным в этой связи является осознание трагедии 2050-х прошлого столетия, который характеризуется разрывом традиций, утратой преемственности культурного опыта. Массовые жертвы и убийства в ходе национально-освободительных движений, гонения представителей религиозных конфессий, выселение в 20-30-е годы мусульманского духовенства (ишанов, имамов, мулл), а также уничтожение целых социальных слоев баев и зажиточных крестьян в ходе насильственной коллективизации; голод, унесший жизни миллионов людей; массовые репрессии против казахской творческой интеллигенции и общественнополитических деятелей, также членов их семей. В ходе которых миллионы людей были лишены жизни, стали узниками ГУЛАГа, были лишены имущества, подвергнуты вынужденной откочевке. Вследствие репрессий республика пережила масштабные социальные катаклизмы. Ярким примером является функционирование «лагерной экономики», создание лагерей - Карлага, Степлага, АЛЖИРа и др.

Также не менее трагичным для Казахстана являются годы Второй мировой войны, которая унесла миллионы жизни людей и неизвестное количество людей до сих пор, которые попали в плен или «без вести» пропавшие. Хотя прошло 75 лет со дня окончания войны массовые поиски продолжаются до сих пор. Сейчас ведется большая работа нашими исследователями, в том числе сотрудниками Института истории и этнологии имени Ч.Ч. Валиханова КН МОН РК по выявлению и возращению добрых имен, которые оказались в плену, после возвращения попали в сталинские лагеря как изменники Родины, судьбы, которых не известны. К большому сожалению, в силу недоступности к архивным материалам исследование этой категории населения до сих пор не имеет своего комплексного фундаментального исследования. Больше материалов имеем из зарубежных открытых архивов, в воспоминаниях очевидцев и свидетелей. Наглядным примером является воспоминание Антанаса Вайчюнаса, литовца, 25 октября 1931 года рождения. Уроженца деревни Гягужяй Паежереляйской волости Шакяйского уезда. 28 апреля 1951 г. был арестован в Каунасе за антисоветскую деятельность и содержался в застенках Каунасской службы госбезопасности. В августе 1951 г. по решению Прибалтийского военного трибунала осужден на 25 лет лагерей и 5 лет ссылки. После суда содержался в Каунасской тюрьме, позднее был переведен в Вильнюсскую пересылочную тюрьму. В ноябре 1951 г. из Вильнюса он был направлен в Челябинскую пересылочную тюрьму. 8 декабря 1951 г. прибыл в лагерь в Джезказгане (Казахстан). С первых дней работал на «Медьбазе», затем на Карпинском карьере, деревообделочном заводе, шахте № 51. Осенью 1955 г. он получил извещение об уменьшении наказания до 7 лет лагерей и 2 лет ссылки. В январе 1956 г. был отпущен на свободу без права возвращения на родину. На несколько месяцев остался в Джезказгане, работал электриком в той же шахте. Когда в мае 1956 г. была отменена и ссылка, вернулся в Литву. С 1956 г. жил в Каунасе, работал на Каунасском радиозаводе и Каунасском станкостроительном заводе им. Ф. Дзержинского. После восстановления независимости Литвы был активным участником государственных праздников, членом избиркома, писал статьи в газеты «Тремтинис» (Ссыльный), «Летувос Айдас» (Эхо Литвы) и др. Умер в Каунасе 22 ноября 2011 года. Воспоминания Антанаса, хранит брат Йонас Вайчюнас, предоставивший нам данный материал [3, c.25]. Этот материал имеет большую ценность тем, что в нем содержатся сведения о бывших военнопленных-казахах, которые отбывали срок наказания у в Джезказгане (Кенгирском лагере). Хотя до этого нам было известно, что там отбывали срок наказания в основном уголовные преступники. Вот что он пишет в своих воспоминаниях о жизни в лагере (Казахстан) о заключенные другие национальности: «Немалую часть лагерных заключенных составляли выходиы из Средней 
Азии: казахи, узбеки, киргизы, туркмены и таджики. Их объединяли три вещи: раса, религия и общая статья 58-1б, по которой они были осуждены за то, что попали в немеикий плен (эта статья предусматривала 25 лет лагерей и 5 лет без права возвращения на родину). Все эти люди за исключением таджиков говорили на тюркских языках. Поскольку они использовали лишь бытовой язык, то небольшие языковые различия не мешали им договариваться между собой. А таджикский язык принадлежит к группе афганских языков. У большинства из них был невысокий уровень интеллекта. За пару часов они изготовляли гитару с двумя струнами и исполняли на ней свои несложные мелодии. Они считали себя незаслуженно осужденными, как сказал один из казахов: «сто русских подняли руки, я один казах, что собака, тоже поднял руки».

Некоторые из среднеазиатских заключенных пытались практиковать свою религию, но условия для этого были крайне неблагоприятными, и таких попыток было немного. Чаще всего они возникали среди таджиков. На литовщев они смотрели благосклонно, с их стороны не было враждебности» [3, c.179]. Подобных фактов, подтверждающие, что очень много военнопленныхказахов отбывали срок наказания в Джезказганском лагере, подтверждают и другие свидетели, которые отбывали срок наказания из числа литовцев, также архивные материалы фондов Центрального Архива Министерства Государственной Безопасности Литовской ССР (ЦА МГБ), в частности это Следственные дела. Также можно сказать о категориях «трудмобилизованные» как представителей депортированных народов, так и казахов в годы войны остается практически не исследованными. В годы войны специальными постановлениями Советского Правительства местное население вместе с контингентами из числа спецпереселенцев были мобилизованы для работ в промышленности и на важнейшие объекты строительства. По постановлению № 492с СНК СССР от 26 сентября 1942 года «О выделении рабочей силы для работы на строительстве нефтепровода... и строительстве Казахстаннефтекомбината» было привлечено, в порядке трудовой повинности, 2350 человек трудоспособного населения (в т.ч. эвакуированное население) [4]. Учитывая особое напряженное положение с погрузкой угля в Карагандинской области, также было мобилизовано 1000 человек [4, Л.1]. Из числа «непригодных к службе в Красной Армии, но пригодных к физическому труду (из них не менее 30 \%) были привлечены к подземным работам на рудниках, для работы на предприятиях Наркомцветмета и Наркомстроя по постановлению № 512-98с СНК КССР. Также было мобилизовано 2250 человек для работы на предприятиях и стройках электростанции Наркомата [4, Л.1], 1000 человек в трест «Прибалхашстрой» для работы на строительстве Балхашского медеплавильного завода [4, Л.29]; 1800 человек - для работы на предприятиях и стройках [4, Л.173].

Трудмобилизованные размещались в специально отведенных «зонах» с заграждениями, с вооруженной охраной и вахтой у ворот. Над ними был поставлен комендант НКВД. В конце 1942 года на территории Казахстана было чуть более 30 Наркоматов и ряд советских учреждении (райсоветы, сельсоветы, нарсуды и редакции газет), где было занято на работах 60293 человека (из них мужчин - 27820, женщин - 28398 и подростков от 14 до 16 лет - 4075) [5, Л.81]. Это данные только одного года. К сожалению, эта категория населения вообще выпала из поля зрения исследования, даже не определен статус, не известно, сколько казахов были мобилизованы в трудовую повинность.

В годы Великой Отечественной войны приобрела свое исключительное значение подготовка квалифицированных рабочих для промышленности и транспорта. Государственные трудовые резервы с первых же дней войны были одной из форм пополнения рабочего класса - в этой системе осуществлялась широкая подготовка квалифицированных кадров для ведущих отраслей промышленности, транспорта и строительства. В связи, чем мобилизация молодежи в школы ФЗО, ремесленные и железнодорожные училища проводилась таким же путем как мобилизация в Трудовую армию - на основе правительственных документов. Вот, например, в 1943 году 27 февраля вышло Постановление № 27с СНК и ЦК КП (б) КазССР «Об очередном призыве молодежи в школы ФЗО, ремесленные и железнодорожные училища (фабрично-заводское обучение), где говорилось: «Обязать Республиканские Управления трудовых резервов для обучения в школы ФЗО, ремесленные и железнодорожные училища в период до марта 1943 года направить 12700 человек городской, колхозной и др. сельскохозяйственной молодежи» [6, Л.39]. Наряду с местным населением призывались, и дети спецпереселенцев и в массовом порядке использовался труд несовершеннолетних детей.

Итак, для продолжения комплексного фундаментального исследования истории неслыханного террора советского государства нужно, нужно иметь доступ к архивным материалам, связанным с политическими репрессиями фонды, которых отражают период репрессий 20-50-х годов, алфавитная картотека и архивные личные дела осужденных, к сожалению пока оставленные в полном объеме до 
особого распоряжения, и необработанные документы общего делопроизводства, которые являются незаменимыми источниками исследования по данной проблеме, особенно материалы 1957-1958 гг., включительно брежневский и андроповский периоды (репрессии за антисоветскую деятельность).

Таким образом, перед учеными, научными исследователями, историками стоит глобальная задача, которая должна стать одним научных приоритетных направлений в исследовательской работе - увековечивание памяти многих миллионов своих граждан, ставших жертвами политических репрессий. Многое из сделанного ранее требует серьезного переосмысления, ряд оценок событий прошлого нуждается в пересмотре. Сейчас идет критическое осмысление принятых по отношению репрессированным народам в 20-50-е годы государственных актов высших органов государственной власти и управления и требуется широкое освещение документами и материалами вопросов реабилитации. Поэтому сегодня необходимо исследование всех компонентов реабилитации, как составной части концепции национальной политики СССР. Для определения направлений в современной национальной политике важно изучить историю и опыт реабилитации необоснованно репрессированных народов в 20-50-е годы прошлого столетия, подвести итоги проведенных мероприятий по реабилитации с учетом специфической особенности проведения в Казахстане, выявить категорий населения не подвергшийся политической либо юридической реабилитации и определить основные направления работы по увековечению памяти жертв политических репрессий. Нет наверно ни одной семьи, судьбы которых не коснулись бы трагедии голода, гонении, репрессии, Великой Отечественной войны. Но в каждой семье бережно хранят память о своих близких, ведь пока мы их помним, они живут в наших сердцах.

На сегодня, реабилитация жертв политических репрессий - это необходимость времени сделать объективный анализ трагических страниц советского периода.

Ссылка на данную статью: Калыбекова М. Ч., Апендиев Т. А. (2020). Архивы говорят: Реабилитация и память. Материалы Международной практической интернет-конференции «Актуальные проблемы науки» [Challenges of Science]. Выпуск III, стр. 150-153.

https://doi.org/10.31643/2020.021

\section{Литературы}

[1] Kalybekova M.Ch., Apendiev T. KAZAKHSTAN GERMANS: TRAGICAL PAGES OF HISTORY// Bulletin National academy of sciences of the Republic of Kazakhstan, 2020. 4(386), 331-338. https://doi.org/10.32014/2020.2518-1467.134

[2] Обращение Главы государства Касым-Жомарта Токаева по случаю Дня памяти жертв политических репрессий и голода от 30 мая $2020 \mathrm{https}: / / w w w . a k o r d a . k z / r u / e v e n t s /$

[3] Калыбекова М., Шеткус Б., Болатхан А. От Балтийского моря до степей Казахстана. -Алматы, 2019. -260 с. 138 ЦГА РК, Ф.1109с, Оп.2с, Д.18, Св.1.

[4] ЦГА РК, Ф.1109с, Оп.2с, Д.18, Св.1.

[5] Архив Комитета по правовой статистике и спецучетам Генеральной Прокуратуры РК, Д.13.

[6] ЦГА РК, Ф.1109с, Оп.2с, Д.28, Св.1, Л.39.

[7] Әпендиев Т. Ә., (2020). Бірінші дүниежүзілік соғыс жылдарында Әулиеата, уезіндегі Германия және АвстроВенгрия тұтқындары. Challenges of Science. Issue III, p.: 83-90. https://doi.org/10.31643/2020.012

\section{References}

[1] Kalybekova M.Ch., Apendiev T. KAZAKHSTAN GERMANS: TRAGICAL PAGES OF HISTORY// Bulletin National academy of sciences of the Republic of Kazakhstan, 2020. 4(386), 331-338. (In English). https://doi.org/10.32014/2020.2518-1467.134

[2] Obrashcheniye Glavy gosudarstva Kasym-Zhomarta Tokayeva po sluchayu Dnya pamyati zhertv politicheskikh repressiy i goloda ot 30 maya 2020 [Address of the Head of State Kassym-Jomart Tokayev on the occasion of the Day of Remembrance of the Victims of Political Repression and Famine, May 30, 2020 https://www.akorda.kz/ru/events/]. (In Russian). https://www.akorda.kz/ru/events/

[3] Kalybekova M., Shetkus B., Bolatkhan A. Ot Baltiyskogo morya do stepey Kazakhstana [From the Baltic Sea to the steppes of Kazakhstan.]. -Almaty, 2019. -260 s. 138 TSGA RK, F.1109s, Op.2s, D.18, Sv.1. (In Russian).

[4] TSGA RK, F.1109s, Op.2s, D.18, Sv.1. (In Russian).

[5] Arkhiv Komiteta po pravovoy statistike i spetsuchetam General'noy Prokuratury RK [Archive of the Committee on Legal Statistics and Special Accounts of the General Prosecutor's Office of the Republic of Kazakhstan], D.13. (In Russian).

[6] TSGA RK, F.1109s, Op.2s, D.28, Sv.1, L.39. (In Russian).

[7] Apendiyev T., (2020). Birinshi duiniezhuizilik sogys zhildarinda aulie ata uezindegi Germaniya zhane Avstro-Vengria tutkyndary [During the first World War Germany and Austria -Hungary prisoners of the Aulie Ata county]. Challenges of Science. Issue III, p.: 83-90. (In Kazakh) https://doi.org/10.31643/2020.012 